\title{
Differential Desensitization and Distribution of Nicotinic Acetylcholine Receptor Subtypes in Midbrain Dopamine Areas
}

\author{
Julian R. A. Wooltorton, Volodymyr I. Pidoplichko, Ron S. Broide, and John A. Dani \\ Division of Neuroscience, Baylor College of Medicine, Houston, Texas 77030-3498
}

\begin{abstract}
Although many psychopharmacological factors contribute to nicotine addiction, midbrain dopaminergic systems have received much attention because of their roles in reinforcement and associative learning. It is generally thought that the mesocorticolimbic dopaminergic system is important for the acquisition of behaviors that are reinforced by the salient drives of the environment or by the inappropriate stimuli of addictive drugs. Nicotine, as obtained from tobacco, can activate nicotinic acetylcholine receptors (nAChRs) and excite midbrain neurons of the mesocorticolimbic system. Using midbrain slices from rats, wild-type mice, and genetically engineered mice, we have found differences in the nAChR currents from the ventral tegmental area (VTA) and the substantia nigra compacta (SNc). Nicotinic AChRs containing the $\alpha 7$ subunit ( $\alpha 7^{\star} \mathrm{nAChRs}$ ) have a low expression density. Electrophysiological analysis of nAChR currents, autoradiography of [ $\left.{ }^{125} \mathrm{I}\right]-\alpha$-bungarotoxin binding, and in situ hybridization revealed that $\alpha 7^{\star}$ nAChRs are more highly expressed in the VTA than the SNc. In contrast, $\beta 2^{\star}$ nAChRs are move evenly distributed at a higher density in both the VTA and SNc. At the concentration of nicotine obtained by tobacco smokers, the slow components of current (mainly mediated by $\beta 2^{\star}$ nAChRs) become essentially desensitized. However, the minority $\alpha 7^{*}$ component of the current in the VTA/SNc is not significantly desensitized by nicotine in the range $\leq 100$ nм. These results suggest that nicotine, as obtained from tobacco, can have multiple effects on the midbrain areas by differentially influencing dopamine neurons of the VTA and SNc and differentially desensitizing $\alpha 7^{\star}$ and non- $\alpha 7 \mathrm{nAChRs}$.
\end{abstract}

Key words: ventral tegmental area; substantia nigra; nicotine addiction; mesolimbic; $\alpha 7 ; \beta 2$

\section{Introduction}

The mesotelencephalic dopaminergic system is heterogeneous and plays many roles (Gardner and Ashby, 2000). Although there is significant overlap, mesostriatal dopamine (DA) neurons originate mainly in the substantia nigra compacta $(\mathrm{SNc})$, and mesocorticolimbic DA neurons originate mainly in the ventral tegmental area (VTA). The dopaminergic systems participate during addiction to amphetamine, cocaine, and nicotine (Clarke, 1990, 1991; Stolerman and Shoaib, 1991; Corrigall et al., 1992; Di Chiara and North, 1992; Nestler, 1992, 1993, 1994; Pontieri et al., 1996; Pich et al., 1997; Di Chiara, 1999, 2000; Balfour et al., 2000; Berke and Hyman, 2000; Dani and De Biasi, 2001; Dani et al., 2001; Hyman and Malenka, 2001).

A role for the midbrain DA system in nicotine addiction is supported by a number of findings (Di Chiara, 2000). Nicotine can support self-administration, and DA antagonists or lesions of DA neurons or of the nucleus accumbens (NAc) reduce selfadministration (Corrigall and Coen, 1989; Corrigall et al., 1992, 1994; Corrigall, 1999). By acting at nicotinic acetylcholine receptors (nAChRs), nicotine can activate VTA and SNc neurons (Clarke et al., 1985; Grenhoff et al., 1986; Calabresi et al., 1989; Pidoplichko et al., 1997; Picciotto et al., 1998) and cause release of

Received July 16, 2002; revised Jan. 17, 2003; accepted Jan. 17, 2003.

This work was supported by grants from the National Institute on Drug Abuse (DA09411, DA12661, DA05947, DA04077), the National Institute of Neurological Disorders and Stroke (NS21229), and the Wellcome Trust, UK. We thank M. W. Quick and R. A. J. Lester for prepublication access to their manuscript.

Correspondence should be addressed to Dr. John A. Dani, Division of Neuroscience, Baylor College of Medicine, One Baylor Plaza, Houston, TX 77030-3498. E-mail: jdani@bcm.tmc.edu.

Copyright $\odot 2003$ Society for Neuroscience $\quad 0270-6474 / 03 / 233176-10 \$ 15.00 / 0$
DA in the NAc of rats (Clarke, 1991; Nisell et al., 1994, 1995; Pontieri et al., 1996). Furthermore, presynaptically located $\mathrm{nAChRs}$ can potently regulate DA release in the striatum, including the NAc (Wonnacott et al., 2000; Jones et al., 2001; Zhou et al., 2001).

Neuronal nAChRs are formed from five subunits, and consequently many compositionally and functionally different nAChRs are possible (McGehee and Role, 1995; Role and Berg, 1996; Wonnacott, 1997; Jones et al., 1999). Five $\alpha$ subunits ( $\alpha 2-$ $\alpha 6)$ and three $\beta$ subunits $(\beta 2-\beta 4)$ can assemble to produce a large number of hetero-oligomeric nAChRs that are distinct but share some functional and pharmacological properties. Most neuronal nAChRs containing the $\alpha 7$ subunit are functionally similar to homo-oligomeric $\alpha 7$ receptors studied in exogenous expression systems, but $\alpha 7$ also may form hetero-oligomeric nAChRs (Yu and Role, 1998). The $\alpha 7 \mathrm{nAChRs}$ have rapid activation and desensitization kinetics and are specifically inhibited by $\alpha$-bungarotoxin ( $\alpha$-BTX) and methyllycaconitine (MLA) (Alkondon et al., 1992; Castro and Albuquerque, 1995; Gray et al., 1996).

The predominant nAChR-mediated currents from VTA and SNc neurons have relatively slow kinetics and are inhibited by the nonspecific inhibitor mecamylamine (Pidoplichko et al., 1997; Picciotto et al., 1998; Klink et al., 2001). Most of these currents are mediated by $\beta 2^{\star} \mathrm{nAChRs}$ because there is a dramatic decrease in these currents when examined from $\beta 2$-null mice (Picciotto et al., 1998). However, many other nicotinic subunits are expressed in these areas, particularly $\alpha 4, \alpha 6$, and $\beta 3$ (Wada et al., 1989, 1990; Le Novère et al., 1996; Goldner et al., 1997; Charpantier et 
al., 1998; Klink et al., 2001). The $\alpha 7$ subunit also is present, but the rapid kinetics of the $\alpha 7^{\star} \mathrm{nAChRs}$ make them very difficult to detect.

The purpose of this study was to examine the contribution of $\alpha 7^{\star} \mathrm{nAChRs}$ in the SNc and the VTA because their high calcium permeability enables them to serve important roles (Séguéla et al., 1993; Castro and Albuquerque, 1995). When comparing AChinduced currents, differences in the density of $\alpha 7^{\star} \mathrm{nAChRs}$ in the SNc and VTA were found. Detection of those $\alpha 7^{\star}$ currents was facilitated by utilization of heterozygous $(+/ \mathrm{T})$, gain-of-function $\alpha$ 7L250T mutant mice (Orr-Urtreger et al., 2000). Furthermore, from the study of both wild-type and $\beta 2$-null $(-/-)$ mice, it was observed that the concentrations of nicotine that are obtained by smokers desensitized the slower components of nicotinic current but had much less effect on the fast $\alpha 7^{\star}$ component.

\section{Materials and Methods}

Midbrain slices and electrophysiology. Midbrain slices containing the VTA and SNc were prepared from 15- to 24-d-old Sprague Dawley rats, wildtype C57BL/6J mice, or mutant mice that were anesthetized before decapitation (Xu et al., 1999; Orr-Urtreger et al., 2000). Slices (300-350 $\mu \mathrm{m}$ thick, rats; $200-250 \mu \mathrm{m}$, mice) were prepared following previously published procedures (Pidoplichko et al., 1997; Zhou et al., 2001). The cutting solution was either of the following and usually a 50/50\% mixture of the two solutions (in $\mathrm{mm}$ ): 230 sucrose, $1 \mathrm{KCl}, 1.25 \mathrm{NaH}_{2} \mathrm{PO}_{4}, 30$ $\mathrm{NaHCO}_{3}, 1 \mathrm{CaCl}_{2}, 7 \mathrm{MgCl}_{2}, 25 \mathrm{D}$-glucose; and $144 \mathrm{NMDG}, 1.5 \mathrm{KCl}, 1.25$ $\mathrm{NaH}_{2} \mathrm{PO}_{4}, 30 \mathrm{NaHCO}_{3}, 2 \mathrm{CaCl}_{2}, 2 \mathrm{MgCl}_{2}, 25$ D-glucose, $30 \mathrm{NaHCO}_{3}$. The slices were then transferred to a holding chamber containing the bath solution (in mM): $125 \mathrm{NaCl}, 2.5 \mathrm{KCl}, 1.25 \mathrm{NaH}_{2} \mathrm{PO}_{4}, 21 \mathrm{NaHCO}_{3}$, $2.5 \mathrm{CaCl}_{2}, 1 \mathrm{MgCl}_{2}, 25$ D-glucose. The experimental chamber $(0.5 \mathrm{ml}$ capacity) had a continuously flowing bath solution $(\sim 5 \mathrm{ml} / \mathrm{min})$ at $32-$ $34^{\circ} \mathrm{C}$. The external solutions contained atropine $(0.25-1 \mu \mathrm{M})$ to block muscarinic ACh receptors, and in some experiments $0.5 \mu \mathrm{M}$ tetrodotoxin was present to inhibit action potentials. Nicotine and the various $\mathrm{nAChR}$ antagonists were applied via the continuously flowing bath solution. Patch electrodes had resistances of 3-5 $\mathrm{M} \Omega$ when filled with the internal solution (in mM): $60 \mathrm{CsCH}_{3} \mathrm{SO}_{3}, 60 \mathrm{KCH}_{3} \mathrm{SO}_{3}, 10 \mathrm{KCl}, 10 \mathrm{EGTA}, 10$ HEPES, $5 \mathrm{Mg}$-ATP, $0.3 \mathrm{Na}_{3} \mathrm{GTP}$, pH 7.2.

Neurons that were patch clamped were identified as dopaminergic on the basis of their appearance and the presence of $I_{\mathrm{h}}$ current (Grace and Onn 1989; Lacey et al., 1989; Hausser et al., 1995; Mercuri et al., 1995; Pidoplichko et al., 1997; Bonci and Malenka, 1999). The presence of $I_{\mathrm{h}}$ was detected by applying hyperpolarizing steps from the holding potential (see Fig. $1 A$, top left panel). Non-dopaminergic neurons in the VTA/ $\mathrm{SNc}$ are usually GABAergic, and they do not display $I_{\mathrm{h}}$ (see Fig. $1 B$, top left panel).

Nicotinic currents were activated by pressure applying ACh using a Picospritzer (General Valve, Parker Hannifin Corporation, Fairfield, NJ) attached to a narrow "puffer" pipette that was pulled like a patch pipette. The puffer pipette was placed $\sim 30 \mu \mathrm{m}$ from the neuron while ACh was applied (1 mM; 28 psi; 30-200 msec duration unless stated otherwise). Then, the puffer was reversibly moved $\sim 100 \mu \mathrm{m}$ away between pressure applications (usually $30-60 \mathrm{sec}$ ) by a computer-controlled motorized manipulator to prevent desensitization caused by agonist leakage. Consistently reproducible $\alpha 7^{\star}$ nAChR currents were measured only by using the above precautions. It should be noted that unless these precautions are taken, especially the fast component of the current (mainly $\alpha 7^{\star}$ ) is underestimated or lost in the larger slower components of the $\mathrm{nAChR}$ current (mainly $\beta 2^{\star}$ ). In mouse slices, currents are more likely to be underestimated because the neurons are smaller and the tissue is denser and less amenable to pressure application of agonist.

Tissue preparation. Tissue for histology was prepared from Sprague Dawley rats on postnatal day (P) $16-21(n=12)$ and from C57BL/6J mice aged P60 $(n=6)$. The rats were used at an age to match the electrophysiology, but because of their smaller size, mice were used at an optimal young age for the histology. Fixed brain tissue for immunohistochemistry was prepared by perfusion with $4 \%$ paraformaldehyde in
PBS, pH 7.4. Brains were equilibrated in $30 \%$ sucrose, frozen, and sectioned $(20 \mu \mathrm{m})$ on a sliding microtome. Unfixed brains were frozen in prechilled isopentane, sectioned on a cryostat $(20 \mu \mathrm{m})$, and mounted onto either gelatin-coated slides for receptor binding or slides with an additional coating of poly-L-lysine for in situ hybridization. Slidemounted sections for in situ hybridization were postfixed with $4 \%$ paraformaldehyde in $0.1 \mathrm{M}$ PBS for $1 \mathrm{hr}$ at $22^{\circ} \mathrm{C}$, washed, and air dried. All sections were stored desiccated at $-20^{\circ} \mathrm{C}$ until use. Histological counterstaining was done with cresyl violet acetate.

Immunohistochemistry. Brain sections for immunohistochemistry were preincubated in PBS containing $0.4 \%$ Triton X-100, 3\% goat serum, and $3 \%$ bovine serum albumin for $1 \mathrm{hr}$ at $22^{\circ} \mathrm{C}$. Sections were then incubated overnight at $4^{\circ} \mathrm{C}$ with an affinity-purified sheep antibody against tyrosine hydroxylase (TH) (Chemicon, Temecula, CA) diluted $(1: 100)$ in the same buffer. After several washes, tissue sections were incubated in biotinylated rabbit anti-sheep antibody (1:200) for $2 \mathrm{hr}$ at $22^{\circ} \mathrm{C}$. Staining for $\mathrm{TH}$ was then visualized using the avidin-biotin immunoperoxidase method (Vectastain, Burlingame, CA) with 3-3'diaminobenzadine tetrahydrochloride (Sigma, St. Louis, MO) as the chromagen.

Receptor binding. Slide-mounted brain sections for $\left[{ }^{125} \mathrm{I}\right]-\alpha$-BTX (specific activity $=10-20 \mu \mathrm{Ci} / \mu \mathrm{g}$; PerkinElmer Life Sciences, Boston, MA) and $\left[{ }^{125} \mathrm{I}\right]$-epibatidine (specific activity $=7383 \mu \mathrm{Ci} / \mu \mathrm{g}$; PerkinElmer Life Sciences) binding were processed as described previously (Broide et al., 2002). After the procedure, sections were placed against $\beta$-max film (Amersham Biosciences, Newark, NJ) for either 3-7 d ([ $\left.{ }^{125} \mathrm{I}\right]-\alpha$-BTX) or 3-12 hr ([ $\left.{ }^{125} \mathrm{I}\right]$-epibatidine).

Autoradiographic images of brain sections showing $\left[{ }^{125} \mathrm{I}\right]-\alpha$-BTX and $\left[{ }^{125} \mathrm{I}\right]$-epibatidine binding site expressions were analyzed, and quantification was performed using computer-assisted densitometry (NIH Image program, developed at the National Institutes of Health, Bethesda, $\mathrm{MD})$. The VTA, SNc, and substantia nigra reticulata ( $\mathrm{SNr}$ ) were identified on corresponding Nissl-stained sections and using rat and mouse brain atlases (Paxinos and Watson, 1996; Paxinos and Franklin, 2000). Specific binding was obtained by subtracting the nonspecific values from total binding values and is presented as mean gray levels. Binding levels in the nearby hippocampus and interpeduncular nucleus were obtained as positive controls. These values were always at least $200 \%$ higher than VTA values. Data was statistically analyzed by a two-tailed Student's $t$ test.

In situ hybridization. Mouse DNA templates encoding the third intracellular loop of the $\alpha 7$ (279 bp) and $\beta 2$ (438 bp) nAChR subunits (Broide et al., 2002) were used to synthesize cRNA riboprobes labeled with $\left[{ }^{35} \mathrm{~S}\right]$ UTP (DuPont NEN, Boston, MA). Postfixed brain sections for in situ hybridization were processed as described previously (Broide et al., 1996). After the procedure, brain sections were placed against $\beta$-max film for $1-7 \mathrm{~d}$ at $4^{\circ} \mathrm{C}$.

Chemicals. Salts, acetylcholine chloride (ACh), ATP (magnesium salt), GTP (sodium salt), mecamylamine (MEC, hydrochloride), $N$-methyl-Dglucamine (NMDG), BAPTA, dihydro- $\beta$-erythroidine (DH $\beta E), C N Q X$, AP-5, bicuculline, and picrotoxin were obtained from Sigma, and MLA (citrate salt) was obtained from Research Biochemicals International (Natick, MA).

\section{Results}

\section{Nicotinic AChR currents from neurons of the VTA and SNc}

DA neurons were identified by the presence of $I_{\mathrm{h}}$ currents (Fig. $1 A$, Ih, DA) (Hausser et al., 1995; Mercuri et al., 1995; Pidoplichko et al., 1997; Bonci and Malenka, 1999). Nicotinic currents were activated by pressure puffs of $1 \mathrm{~mm} \mathrm{ACh}$, and some neurons expressed more than one kinetic component (Fig. 1A). The amplitudes of the ACh-induced currents are given in Table 1, and a component had to be $>15 \mathrm{pA}$ to be accepted and analyzed. A minority of DA neurons from the VTA displayed nAChR currents with both fast and slow components: 10 of 33 neurons from rats and 11 of 47 neurons from mice. The fast component of this current was inhibited by MLA ( $5 \mathrm{~nm})$. Both the kinetics and pharmacology indicate that the fast component was mediated by 

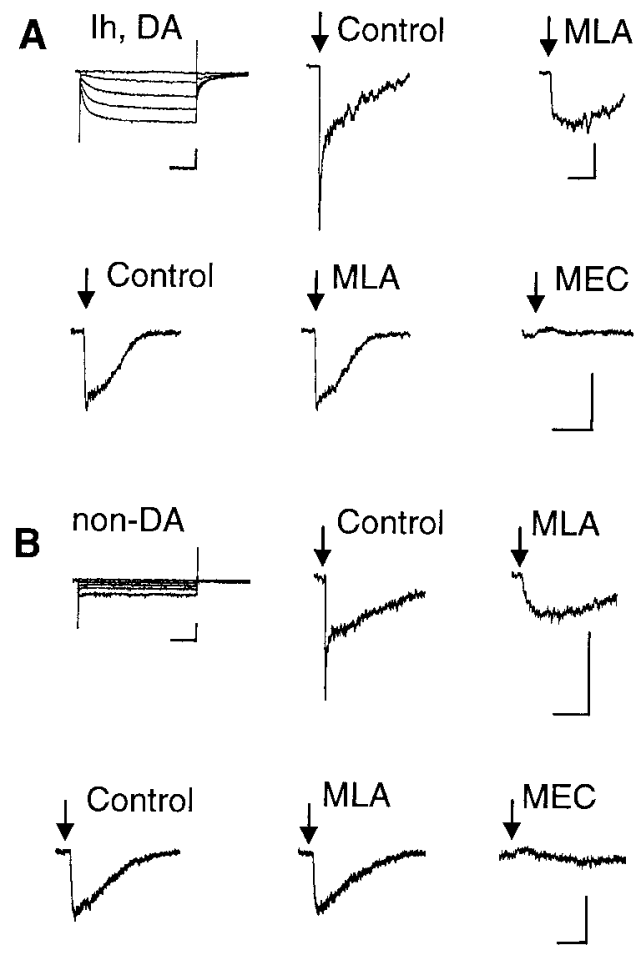

Figure 1. ACh-evoked currents from VTA neurons. $A$, The $I_{\mathrm{h}}$ currents indicate a DA neuron. Puffs of $A C h$ ( $40 \mathrm{msec} ; 1 \mathrm{~mm} \mathrm{ACh}$ ) induced currents with two components in the top row. The fast component is inhibited by the $\alpha 7$-specific inhibitor MLA ( $5 \mathrm{nM}$ ). The slow current in the bottom row is not inhibited by MLA, but it is inhibited by $5 \mu \mathrm{M} M E C$. $B$, The absence of $I_{\mathrm{h}}$ indicates a non-DA neuron. The ACh-induced current ( $100 \mathrm{msec}$ puff of $1 \mathrm{~mm} A C h$ ) shows two components in the top row. The fast component is inhibited by $5 \mathrm{~nm} M L A$. The slow current in the bottom row is not inhibited by MLA, but it is inhibited by $5 \mu \mathrm{M}$ MEC. The ACh puffs were applied once every $60 \mathrm{sec}$. Each trace is an average of three currents. Calibration: $50 \mathrm{pA}, 0.5 \mathrm{sec}$ for the $\mathrm{ACh}$-induced currents; $200 \mathrm{pA}, 0.5 \mathrm{sec}$ for the $I_{\mathrm{h}}$ protocols.

$\alpha 7^{\star}$ nAChRs. The fast component of the current was seen only once without the accompanying slower component: 0 of 33 in rat and 1 of 47 in mice. The slower component was usually present in measurements from VTA DA neurons: 33 of 33 from rats and 42 of 47 from mice. With rare exceptions, the slow component of the current was unaffected by $20 \mathrm{nM}$ MLA, but it was rapidly and completely inhibited by MEC (1-10 $\mu \mathrm{M})$ (Fig. $1 A)$. This concentration of MEC is rather nonselective, inhibiting most types of hetero-oligomeric nAChRs. MEC (especially above $5 \mu \mathrm{M}$ ) applied for longer times also inhibited the fast currents mediated by $\alpha 7^{\star} \mathrm{nAChRs}$ (data not shown). In 4 of 47 DA neurons from mice, no $\mathrm{nAChR}$ currents were detected. This result does not guarantee that nAChRs are not present in those neurons; rather, they simply did not mediate significant current at the position of the ACh puffer pipette.

Non-dopaminergic neurons in the VTA (usually considered GABAergic) were identified by the absence of $I_{\mathrm{h}}$ (Fig. $1 \mathrm{~B}$, non-
DA). Those neurons displayed nicotinic currents similar to those of DA neurons (Fig. $1 \mathrm{~B}$ ). Only a minority displayed both the fast (MLA-sensitive) and the slow (MEC-sensitive) components of current: 9 of 29 from rats and 8 of 31 from mice. The fast component without the accompanying slower component was seen in 0 of 29 rat neurons and in 1 of 31 mouse neurons. In contrast, the slower component was usually present in measurements from VTA non-DA neurons: 22 of 29 from rats and 27 of 31 from mice. As in DA neurons, this slow component was completely inhibited by $5 \mu \mathrm{M}$ MEC (Fig. 1 B). In 7 of 29 non-DA neurons from rats and in 3 of 31 non-DA neurons from mice, no nAChR currents were detected.

All of the neurons that we studied from the SNc possessed an $I_{\mathrm{h}}$ current, indicating that they were dopaminergic neurons. In the SNc the fast component of nAChR current was more rare, and it was detected significantly in only 1 of $23 \mathrm{SNc}$ neurons from rat and 3 of 37 from mice. In contrast, the slow component of the current was seen in 22 of 23 rat SNc neurons and in 31 of 37 mouse SNc neurons. No nicotinic currents were observed in 1 of 23 SNc DA neurons from rats and in 6 of 37 SNc DA neurons from mice.

Usually the ACh pressure applications that we used were $30-$ $200 \mathrm{msec}$ in duration. Those ACh puffs revealed two pharmacologically distinct components of the current: a fast component inhibited by $1 \mathrm{nM}$ MLA and a slow component inhibited by $1 \mu \mathrm{M}$ $\mathrm{DH} \beta \mathrm{E}$. An additional observation was that longer puffs of ACh (2000 msec) revealed an even slower component of the current (data not shown). That current was inhibited by $1 \mu \mathrm{M}$ MEC, indicating that it was arising from another nAChR type, or types, that was not sensitive to $1 \mathrm{nM}$ MLA or $1 \mu \mathrm{M} D H \beta E$. Thus, the slower components of current are composed of multiple nAChR types, some of which are sensitive to $\mathrm{DH} \beta \mathrm{E}$ and others to MEC.

\section{Mice lacking the $\beta 2$ subunit have predominantly \\ MLA-sensitive currents}

Because the slow component of the current could obscure the smaller fast component, we examined $\beta 2$-null mice to eliminate the vast majority of the slow current. In these experiments, we took special care to avoid secondary conductances that were indirectly activated by $\alpha 7 \mathrm{nAChRs}$. Intracellular $\mathrm{Ca}^{2+}$ was strongly buffered by BAPTA (20 mM) to prevent $\mathrm{Ca}^{2+}$-dependent conductances that may have been initiated by $\alpha 7$ activity. GABA and glutamate channels were inhibited by bicuculline $(20 \mu \mathrm{M})$, CNQX $(20 \mu \mathrm{M})$, and AP-5 $(100 \mu \mathrm{M})$ to prevent synaptic currents potentially induced by presynaptic $\alpha 7 \mathrm{nAChR}$ activity. Fast small currents (notches in the current trace) were detected more easily in the $\beta 2$-null mice. For that reason a higher percentage of neurons were positive for fast currents, but the conclusions about the putative $\alpha 7$-mediated currents were similar to those obtained using the wild-type mice (Table 2). The MLA-sensitive currents were more common in the VTA than in the SNc neurons. On a few occasions (Table 2), a slow current that was not inhibited by

Table 1. Nicotinic AChR currents from wild-type rodent VTA DA, VTA non-DA, and SNc DA neurons ${ }^{a}$

\begin{tabular}{|c|c|c|c|c|c|c|c|}
\hline \multirow[b]{2}{*}{ Current } & \multicolumn{3}{|l|}{ Rat } & \multicolumn{4}{|l|}{ Mouse } \\
\hline & VTA DA & VTA non-DA & SNCDA & Current & VTA DA & VTA non-DA & SNCDA \\
\hline Fast & $\begin{array}{l}90 \pm 20 \mathrm{pA} \\
(10 / 33)\end{array}$ & $\begin{array}{l}130 \pm 40 \mathrm{pA} \\
(9 / 29)\end{array}$ & $\begin{array}{l}50 \mathrm{pA} \\
(1 / 23)\end{array}$ & Fast & $\begin{array}{l}70 \pm 20 \mathrm{pA} \\
(11 / 47)\end{array}$ & $\begin{array}{l}90 \pm 40 \mathrm{pA} \\
(8 / 31)\end{array}$ & $\begin{array}{l}40 \pm 10 \mathrm{pA} \\
(3 / 37)\end{array}$ \\
\hline Slow & $\begin{array}{l}110 \pm 20 \mathrm{pA} \\
(33 / 33)\end{array}$ & $\begin{array}{l}120 \pm 30 \mathrm{pA} \\
(22 / 29)\end{array}$ & $\begin{array}{l}130 \pm 5 \mathrm{pA} \\
(22 / 23)\end{array}$ & Slow & $\begin{array}{l}83 \pm 7 p A \\
(42 / 47)\end{array}$ & $\begin{array}{l}77 \pm 8 p A \\
(27 / 31)\end{array}$ & $\begin{array}{l}78 \pm 9 p A \\
(31 / 37)\end{array}$ \\
\hline None & $(0 / 33)$ & $(7 / 29)$ & $(1 / 23)$ & None & $(4 / 47)$ & $(3 / 31)$ & $(6 / 37)$ \\
\hline
\end{tabular}

${ }^{a}$ Currents are given as mean \pm SEM. Numbers in parentheses indicate the number of responding neurons/total number of neurons investigated. Note the lower incidence of the fast nAChR-mediated current in SNc DA neurons, compared with VTA neurons, in contrast to the similar incidence of the slow current in all neuronal subsets studied. 
Table 2. Nicotinic AChR currents from $\beta 2-/-$ mouse VTA DA, VTA non-DA, and SNc DA neurons ${ }^{a}$

\begin{tabular}{llll}
\hline Current & VTA DA & VTA non-DA & SNc DA \\
\hline Fast & $40 \pm 7 \mathrm{pA}(21 / 37)$ & $47 \pm 16 \mathrm{pA}(6 / 12)$ & $38 \pm 17 \mathrm{pA}(3 / 20)$ \\
Slow & $65 \pm 22 \mathrm{pA}(5 / 37)$ & $47 \mathrm{pA}(1 / 12)$ & $35 \mathrm{pA}(1 / 20)$ \\
None & $(12 / 37)$ & $(5 / 12)$ & $(16 / 20)$ \\
\hline
\end{tabular}

${ }^{a}$ Currents are given as mean \pm SEM. Numbers in parentheses indicate the number of responding neurons/total number of neurons investigated.

MLA ( $5 \mathrm{~nm}$ ) or $\mathrm{DH} \beta \mathrm{E}(2 \mu \mathrm{M})$ was observed. Although other explanations are possible, this minority current could involve $\beta 3^{\star}$ nAChRs (Le Novère et al., 1996).

Mice with the gain-of-function $\alpha 7 \mathrm{~L} 250 \mathrm{~T}$ mutation have larger MLA-sensitive currents

Often the fast, putative $\alpha 7^{\star}$ component of the ACh-induced currents was small. Because some $\alpha 7^{\star}$ currents were below our level of acceptance in wild-type mice (15 pA), we were underestimating the percentage of neurons that contained the $\alpha 7$ subunit. To obtain a better estimate, we took advantage of heterozygote mutant mice ( $+/ \mathrm{T}$ ) having one copy of the $\alpha 7$ subunit with a leucine to threonine mutation ( $\alpha 7 \mathrm{~L} 250 \mathrm{~T}$ ) (Orr-Urtreger et al., 2000; Ji et al., 2001). In these mutant mice the $\alpha 7$ subunit is thought to be expressed at lower concentrations than in wild-type mice (OrrUrtreger et al., 2000), but this L250T mutation causes the $\alpha 7^{\star}$ currents to appear larger and slower (Fig. 2) (Revah et al., 1991; Bertrand et al., 1992; Ji et al., 2001). Thus, the $\alpha 7^{\star}$ nAChRs currents are much easier to detect. In the +/T mice, larger MLAsensitive currents were seen in all of the VTA DA neurons $(n=10$ of 10) (Fig. $2 B, F)$ and in the majority of SNc DA neurons $(n=14$ of 17) (Fig. $2 D, F)$. In both mutant $\alpha 7 \mathrm{~L} 250 \mathrm{~T}$ mice $(+/ \mathrm{T})$ and wild-type mice $(+/+)$, the putative $\alpha 7^{\star}$ currents from SNc neurons were significantly smaller $(p<0.05)$ than those from VTA DA neurons (Fig. 2E, Table 3).

To further verify that this MLA-sensitive component of the current was arising from $\alpha 7^{\star}$ type nAChRs, we activated the nAChRs with choline (Table 3), a relatively specific $\alpha 7^{\star}$ agonist (Papke et al., 1996; Alkondon et al., 1997; Zwart and Vijverberg, 2000). Pressure applications of choline ( $10 \mathrm{~mm}, 40 \mathrm{msec})$ induced reproducible, MLA-sensitive currents in +/T neurons in 6 of 6 VTA DA neurons (Fig. 3A), in 8 of 9 VTA non-DA neurons (Fig. $3 B$ ), and in 17 of $18 \mathrm{SNc}$ DA neurons (Fig. $3 C$ ). The cholineinduced $\alpha 7^{\star}$ currents were significantly larger $(p<0.001)$ in the VTA than in the SNc (Fig. 3D, Table 3). Especially in these experiments, the puffer pipette was repeatedly positioned for a number of trials to find an area of the neuron (usually dendrites) that responded well to the choline puff.

An additional observation in these heterozygous $\alpha 7 \mathrm{~L} 250 \mathrm{~T}$ $(+/ \mathrm{T})$ mice was that $5 \mathrm{~nm}$ MLA added to the bath decreased the holding current necessary to voltage clamp the cells $(n=9$; data not shown). This result is expected because a proportion of the homomeric $\alpha 7 \mathrm{nAChRs}$ expressed in the neurons are composed of all $\alpha 7 \mathrm{~L} 250 \mathrm{~T}$ subunits, which have been reported to be open in the absence of applied agonist (Revah et al., 1991; Bertrand et al., 1992).

\section{Anatomical confirmation of greater $\alpha 7$ expression in the VTA} than in the $\mathrm{SNc}$

The ACh- and choline-induced currents indicated that the putative $\alpha 7^{\star}$ component was larger in the VTA than in the SNc. We wanted an independent method to verify the conclusions drawn from the current measurements for the following reasons. $\alpha 7^{\star}$
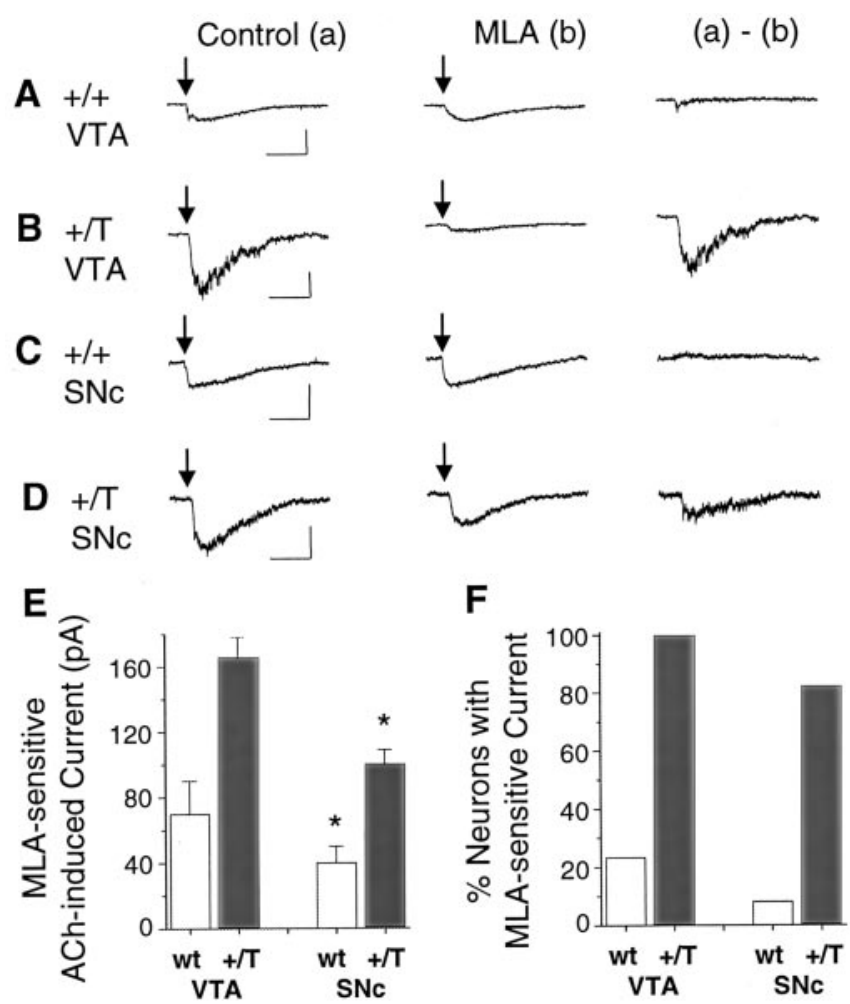

Figure 2. Mice expressing mutant $\alpha$ 7L250T subunits display much larger MLA-sensitive currents. Pressure applications of $1 \mathrm{~mm}$ ACh (arrows) elicited currents from a wild-type VTA DA neuron $(A)$, from a mutant +/T VTA DA neuron $(B)$, from a wild-type SNc DA neuron $(C)$, and from a mutant $+/$ T SNc DA neuron $(D)$. In each case, $(a)$ denotes the control current and $(b)$ denotes the current recorded in the presence of MLA. The $(a)-(b)$ subtraction shows the net MLA-sensitive current. As expected, the $\alpha$ 7L250T mutation produces larger and slower AChinduced currents. The ACh puffs were 30-60 msec in duration for $A, B$, and $D$, but 200 msec in C.E, The bar graphs compare the magnitude of the MLA-sensitive currents in the VTA or SNc and from wild-type or $+/ T$ mice. $F$, The bar graphs compare the proportion of the sampled neurons with MLA-sensitive current in the VTA or SNc and from wild-type or +/T mice. Calibration: 200 $\mathrm{pA}(A, B), 50 \mathrm{pA}(C, D), 0.5 \mathrm{sec} .{ }^{*} p<0.05$ significantly different from corresponding VTA values by Student's $t$ test.

Table 3. Nicotinic AChR currents from $\alpha 7+/$ mouse VTA DA, VTA non-DA, and SNC DA neurons $^{a}$

\begin{tabular}{llll}
\hline $\begin{array}{l}\text { MLA-sensitive } \\
\text { current }\end{array}$ & VTA DA & VTA non-DA & SNc DA \\
\hline ACh induced & $166 \pm 12 \mathrm{pA} \mathrm{(10/10)}$ & $40 \mathrm{pA}(1 / 1)$ & $101 \pm 8 \mathrm{pA}(14 / 17)$ \\
None & $(0 / 10)$ & $(0 / 1)$ & $(3 / 17)$ \\
Choline induced & $504 \pm 119 \mathrm{pA} \mathrm{(6/6)}$ & $299 \pm 71 \mathrm{pA}(8 / 9)$ & $149 \pm 21 \mathrm{pA}(17 / 18)$ \\
None & $(0 / 6)$ & $(1 / 9)$ & $(1 / 18)$ \\
\hline
\end{tabular}

$\overline{{ }^{a} \text { Currents are given as mean } \pm \text { SEM. Numbers in parentheses indicate the number of responding neurons/total }}$ number of neurons investigated.

currents are difficult to measure and are sometimes not seen (Picciotto et al., 1998), and a significant component of non- $\alpha 7$, MLA-sensitive current has been reported in the VTA/SNc (Klink et al., 2001). The $\alpha 7$ subunit participates in (most if not all) the high-affinity binding sites for $\alpha$-BTX in the brain (Orr-Urtreger et al., 1997; Whiteaker et al., 2000). Therefore, we used $\left[{ }^{125} \mathrm{I}\right]$ $\alpha$-BTX binding in rat and mouse midbrain sections to semiquantitatively indicate the presence of the $\alpha 7$ subunit.

In the rat, $\left[{ }^{125} \mathrm{I}\right]-\alpha$-BTX binding was detected in the VTA and the SNc (Fig. 4). The $\left[{ }^{125} \mathrm{I}\right]-\alpha$-BTX binding was specific to the $\alpha 7^{\star}$ nAChRs because it was displaced by the competitive antagonist, $10 \mu \mathrm{M} \alpha$-cobratoxin (Cbt) (Fig. $4 A, B$ ). The location of the $\alpha$-BTX binding sites was identified as the VTA/SN by immuno- 

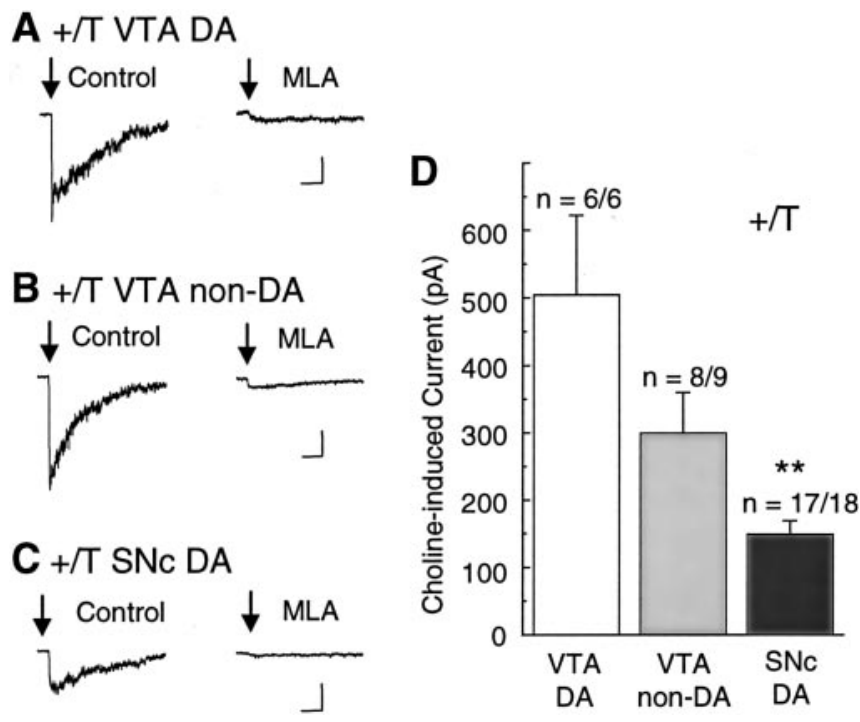

Figure 3. Choline-activated currents from $+/ \mathrm{T}$ mice ( $\alpha 7 \mathrm{~L} 250 \mathrm{~T})$ are larger, slower, and inhibited by MLA. A, Typical currents obtained from a VTA DA neuron. At the arrow, $10 \mathrm{~mm}$ choline is pressure puffed for $40 \mathrm{msec}$ (once every $2 \mathrm{~min}$ ). The current was inhibited by $5 \mathrm{~nm} \mathrm{MLA}$. $B$, Similar MLA-sensitive currents were observed in VTA non-DA neurons. C, Typical cholineactivated, MLA-inhibited currents are shown from an SNc DA neuron. Three traces were averaged for each representative current. Calibration: $100 \mathrm{pA}, 0.5 \mathrm{sec}$. D, Bar graphs representing average amplitudes of choline-evoked currents recorded from VTA DA, VTA non-DA, and SNc DA neurons of $+/$ T mice. ${ }^{* *} p<0.001$ significantly different from VTA values by Student's $t$ test.

histochemically labeling sections from the same brain region for tyrosine hydroxylase, an enzyme required for dopamine synthesis (Fig. 4D). Mean levels of [ $\left.{ }^{125} \mathrm{I}\right]-\alpha$-BTX binding site density in the VTA, SNc, and SNr were determined from autoradiographic images of brain sections (Fig. $4 E$ ). Levels of [ $\left.{ }^{125} \mathrm{I}\right]-\alpha$-BTX binding were significantly higher in the VTA than in the SNc, despite the fact that the density of DA neurons is higher in the SNc (Fig. 4 , compare $A, C, E$ ). A caveat in these measures is that the $\alpha$-BTX binding sites could be located on afferent synaptic terminals rather than on the cell bodies. The rats used for these anatomical studies were about the same age $(\mathrm{P} 16-21)$ as the rats used for electrophysiology (P15-24). By using the same age, changes in $\alpha 7$ expression during development could be avoided in our comparison of the anatomical and electrophysiological results.

Mouse midbrain sections likewise exhibited a significantly higher level of $\left[{ }^{125} \mathrm{I}\right]-\alpha$-BTX binding in the VTA than in the SNc (Fig. $5 A, E$ ). To confirm those results and to identify the midbrain DA regions expressing $\alpha 7$ subunit mRNA, in situ hybridization was performed on adjacent brain sections (Fig. 5B). Levels of $\alpha 7$ mRNA expression were higher in the VTA than in the SNc, corresponding to the pattern of $\left[{ }^{125} \mathrm{I}\right]-\alpha$-BTX binding. The mice used for these anatomical studies were older (P60) than the mice used for electrophysiology (P15-24). Potential changes in $\alpha 7$ expression during development were not examined. Despite the difference in age, however, both sets of experiments suggest that $\alpha 7^{\star}$ nAChRs are more commonly expressed in the mouse VTA than in the SNc.

To determine whether this distribution pattern was the same for all $\mathrm{nAChR}$ types, we characterized the distribution of $\left[{ }^{125} \mathrm{I}\right]$ epibatidine binding and $\beta 2 \mathrm{nAChR}$ subunit mRNA. Epibatidine binds with various affinities to a number of non- $\alpha 7 \mathrm{nAChR}$ subtypes, most of which contain $\beta 2$ (Whiteaker et al., 2000). Both the VTA and SNc displayed comparable and high levels of $\left[{ }^{125} \mathrm{I}\right]$ epibatidine binding (Fig. 5C,E). In agreement with that result, the

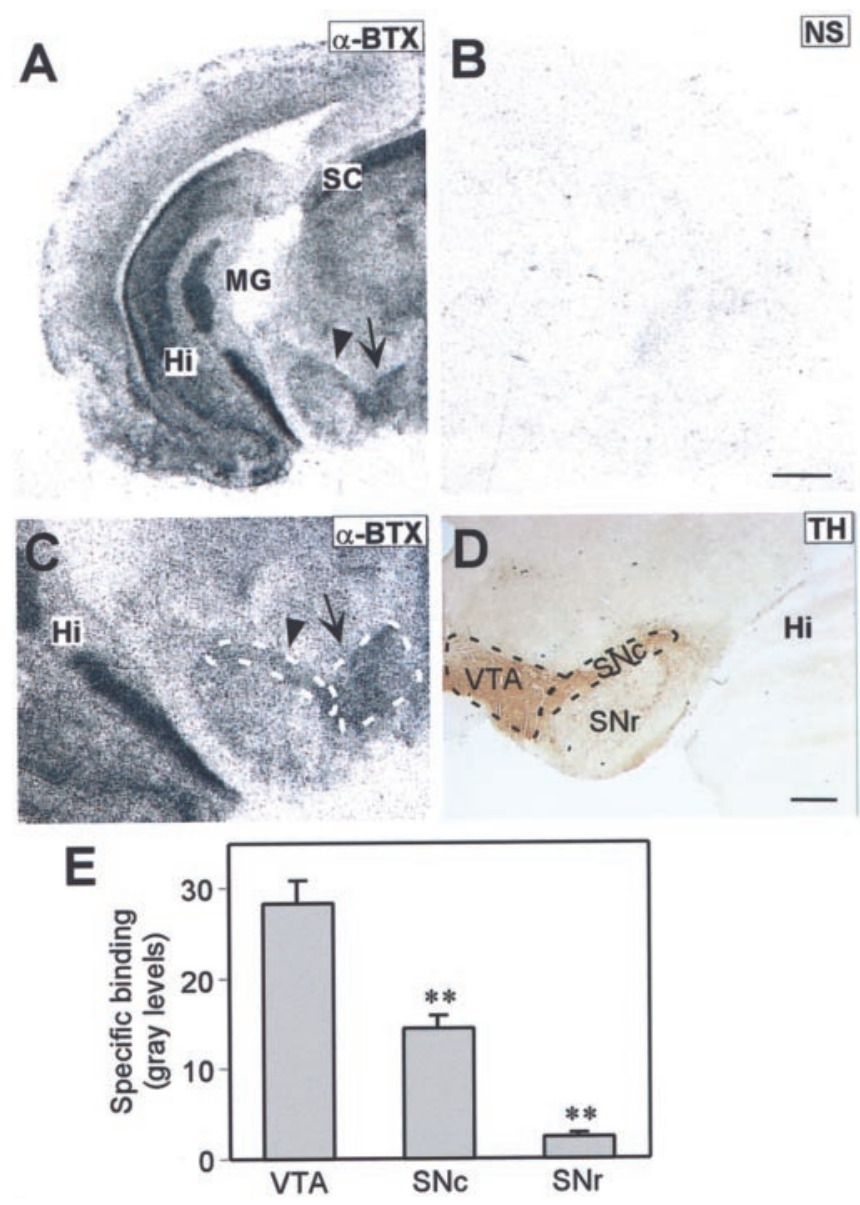

Figure 4. Distribution of $\alpha$-BTX binding sites in the midbrain dopaminergic region of the rat. $A$, An autoradiographic image of a coronal section through the rat midbrain dopaminergic regions shows the $\left[{ }^{125} \mathrm{I}\right]-\alpha$-BTX binding-site distribution. The arrow indicates the VTA, and the arrowhead indicates the SNc. $B$, An autoradiographic image of $\left[{ }^{125} \mathrm{I}\right]-\alpha$-BTX binding in an adjacent coronal section through the same region after specifically blocking the $\alpha$-BTX sites with $\alpha$-Cbt, indicating nonspecific binding (NS). C, Higher magnification of the VTA/SNc area shown in A. D, Staining for tyrosine hydroxylase (TH) delineates the VTA, SNc, and SNr in the midbrain dopaminergic region. $E$, The bar graph depicts the density of $\left[{ }^{125} \mathrm{I}\right]-\alpha-\mathrm{BTX}$ bindingsite expression in the VTA, SNc, and SNr. The values represent specific binding in gray levels and are means \pm SEM from seven rat brains. ${ }^{* *} p<0.001$ significantly different from VTA values by Student's t test. Hi, Hippocampus; MG, medial geniculate; SC, superior colliculus; SNc, substantia nigra compacta; SNr, substantia nigra reticulata; VTA, ventral tegmental area. Scale bars: $A$, $B, 1000 \mu \mathrm{m} ; C, D, 500 \mu \mathrm{m}$.

pattern of $\beta 2$ mRNA expression was similar in the VTA and SNc (Fig. 5D).

\section{Nicotine at the concentrations obtained from tobacco differentially desensitizes the $\mathrm{nAChR}$ subtypes}

It has been shown previously that the higher concentrations of nicotine achieved by smokers (i.e., 100-500 nM) can desensitize nAChR currents from VTA DA neurons (Pidoplichko et al., 1997). We extended the examination of desensitization to lower nicotine concentrations $(20-80 \mathrm{~nm})$ that are present in smokers for longer times. Bath application of $80 \mathrm{~nm}$ nicotine strongly desensitized the slow component (mainly $\beta 2^{*} \mathrm{nAChRs)}$ of the ACh-induced current: $82 \pm 4 \%, n=7$ for VTA DA neurons (Fig. $6 A) ; 80 \pm 7 \%, n=10$ for VTA non-DA neurons (Fig. $6 B$ ). The time course of desensitization in the slices is shown in Figure $6 C$. Bath application of $20 \mathrm{~nm}$ nicotine also was sufficient to cause substantial desensitization of the slow component of ACh- 

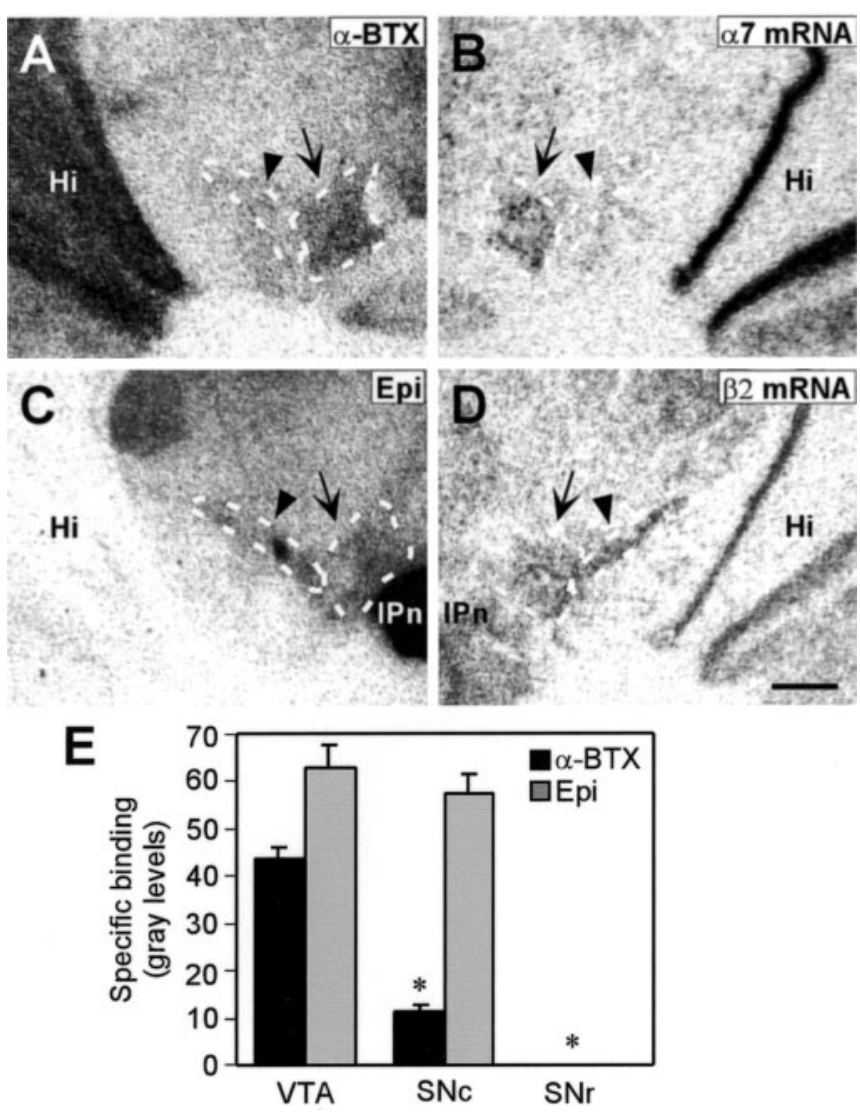

Figure 5. Distributions of $\alpha 7$ and non- $\alpha 7 \mathrm{nAChRs}$ in the midbrain dopaminergic region of the mouse. Autoradiographic images of alternate coronal sections through the midbrain dopaminergic region showing the distributions of [ [ $\left.{ }^{125} \mid\right]-\alpha$-BTX binding sites $(A), \alpha 7 \mathrm{nAChR}$ subunit mRNA $(B),\left[{ }^{125} \mathrm{l}\right]$-epibatidine binding sites $(C)$, and $\beta 2 \mathrm{nAChR}$ subunit mRNA $(D)$. The arrow indicates the VTA, and the arrowhead indicates the SNc. E, The bar graph depicts the density of $\left[{ }^{125} \mid\right]-\alpha$-BTX and [ $\left.{ }^{125} \mid\right]$-epibatidine (Epi) binding site expression in the VTA, SNc, and SNr. The values represent specific binding in gray levels and are means \pm SEM from three mouse brains. ${ }^{*} p<0.01$ significantly different from VTA values by Student's $t$ test. Hi, Hippocampus; IPn, interpenduncular nucleus. Scale bar, $500 \mu \mathrm{m}$.

induced current: $45 \pm 4 \%, n=6$ from VTA DA neurons (Fig. $7 A)$. However, $20 \mathrm{~nm}$ nicotine did not desensitize the fast component of the current during a $20 \mathrm{~min}$ exposure $(n=3)$ (Fig. $7 B, C)$. In most cases, the fast and slow components of the current were not easily separable. Measurement of the fast component was often contaminated by the rising phase of the slow component, particularly when the slow component was the predominant current (Fig. 7C).

To characterize desensitization of the fast component (putative $\alpha 7^{\star}$ ), we used mutant mice lacking the $\beta 2 \mathrm{nAChR}$ subunit. In the absence of the $\beta 2$ subunit, the ACh-induced currents were mainly of the fast, $\alpha 7^{\star}$ variety. The fast component of the current was not significantly desensitized by bath-applied nicotine in the range experienced by smokers ( $80-500 \mathrm{~nm} ; 20 \mathrm{~min} ; n=4$ ) (Fig. $8)$. The ACh-induced currents from $\beta 2-/-$ neurons were inhibited by 5 nM MLA (Fig. $8 D$ ) $(n=8$ of 8 ) but were not inhibited by $1 \mu \mathrm{M} \mathrm{DH} \beta \mathrm{E}$, as expected, in one trial (Fig. $8 E$ ). These results further support the possibility that the fast component of the current that we studied was mediated by $\alpha 7^{\star}$ nAChRs.

\section{Discussion}

Although the $\alpha 7^{\star}$ nAChRs are expressed at a low density, they are commonly present in neurons of the midbrain DA areas. Evi-
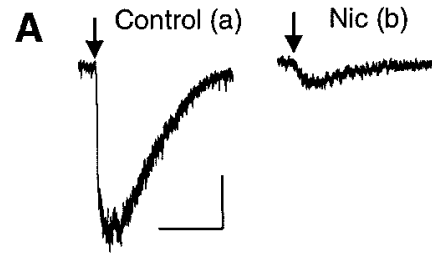

(a) - (b)
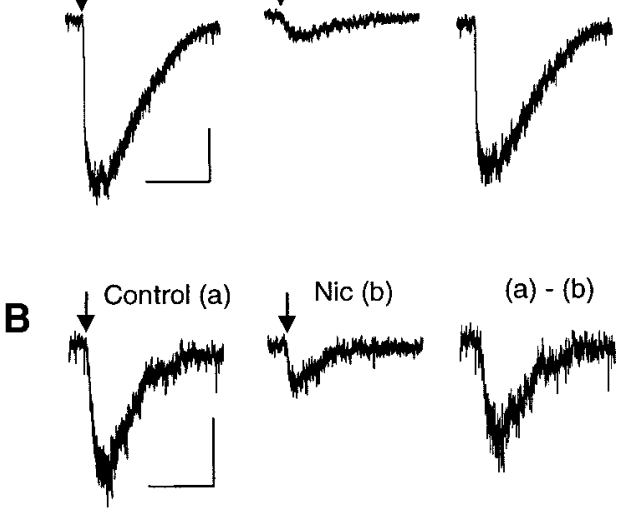

(a) - (b)

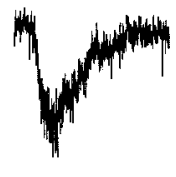

C

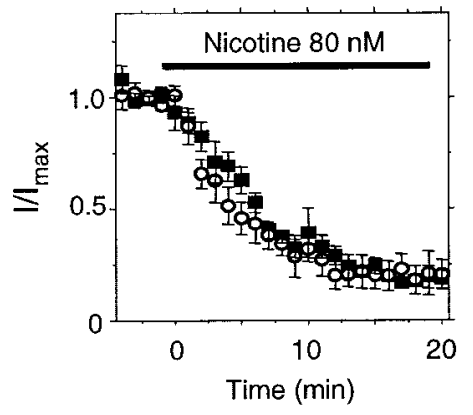

Figure 6. A20 min exposure to low concentrations of nicotine desensitizes the slow component of current from VTA DA and non-DA wild-type neurons. Responses to pressure applications of ACh (arrows) are shown for a VTA DA neuron $(A)$ and for a non-DA neuron $(B)$ in the absence $(a)$ and presence $(b)$ of $80 \mathrm{~nm}$ nicotine (Nic). The (a) - (b) subtraction shows the net nicotinedesensitized current. C, The average time course of desensitization is shown in response to $80 \mathrm{~nm}$ nicotine for the slow component of current from VTA DA neurons $(\boldsymbol{\square} ; n=7)$ and non-DA neurons $(\bigcirc ; n=10)$. Calibration: $25 \mathrm{pA}, 1 \mathrm{sec}$.

dence indicates that the VTA/SNc contains $\alpha 3-\alpha 7$ and $\beta 2-\beta 4$, and $\alpha 4, \alpha 6$, and $\beta 2$ are common participants in nAChRs from this region (Le Novère et al., 1996; Picciotto et al., 1998; ArroyoJimenez et al., 1999; Klink et al., 2001; Azam et al., 2002; Champtiaux et al., 2002). Our evidence indicates that the fast current mediated by the putative $\alpha 7^{\star}$ nAChR type is found at low levels in many of the VTA/SNc neurons. This component of the current is most likely mediated by $\alpha 7^{\star}$ nAChRs for the following reasons. (1) When activated by high agonist concentrations, the current has rapid kinetics. (2) The current is greatly enhanced by the $\alpha 7 \mathrm{~L} 250 \mathrm{~T}$ mutation. (3) The current is activated by the relatively specific agonist, choline. (4) The relatively specific inhibitor, MLA, inhibits the current. (5) The current amplitudes are consistent with the distribution of the $\left[{ }^{125} \mathrm{I}\right]-\alpha-\mathrm{BTX}$ binding sites. (6) The current is present in $\beta 2$-null mice. When current was measured from wild-type mice, the putative $\alpha 7^{\star}$ component was difficult to detect, and we detected this component only $23 \%$ (Table 1) of the time from mouse VTA DA neurons and $8 \%$ from mouse SNc DA neurons. However, when taking advantage of the $\beta 2$-null mice, we detected this current more often (Table 2), and in $\alpha 7 \mathrm{~L} 250 \mathrm{~T}$ gain-of-function mice, it was detected in the vast majority of the VTA/SNc neurons (Table 3). Thus, the low copy number for the $\alpha 7$ subunit could be overcome in the $\alpha 7 \mathrm{~L} 250 \mathrm{~T}$ mice because we could detect the opening of only a few $\alpha 7 \mathrm{~L} 250 \mathrm{~T}^{*}$ channels. Without the advantages of the $\alpha 7 \mathrm{~L} 250 \mathrm{~T}$ mutation and experimental care to have rapid agonist applications that also 

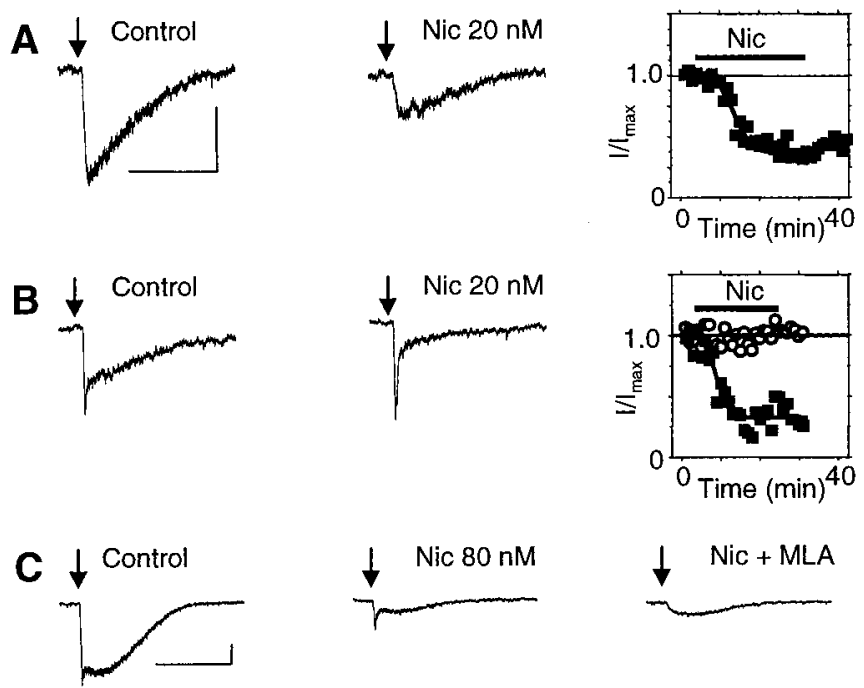

Figure 7. Exposure to low concentrations of nicotine differentially desensitize fast and slow nicotinic currents from mouse VTA DA neurons. $A$, ACh-induced currents (arrow) in the absence (Control) and presence (Nic) of $20 \mathrm{~nm}$ nicotine. The time course of the nicotine-induced desensitization for this neuron is shown on the right. $B$, Nicotine $(20 \mathrm{~nm})$ desensitizes the slow component of current, but the fast component is not significantly desensitized. The time course of the nicotine-induced desensitization for this neuron is shown separately for the slow ( $\square$ ) and fast $(\bigcirc)$ components of current. $C$, In this common example, the fast component of the AChinduced current is difficult to separate from the larger slow component of current in the absence of nicotine (Control). After exposure to $80 \mathrm{~nm}$ nicotine (Nic), the small, fast component is easier to see. The fast component is inhibited by MLA (Nic + MLA). Calibration: $50 \mathrm{pA}, 1 \mathrm{sec}$.

\section{$\beta 2-/-$}
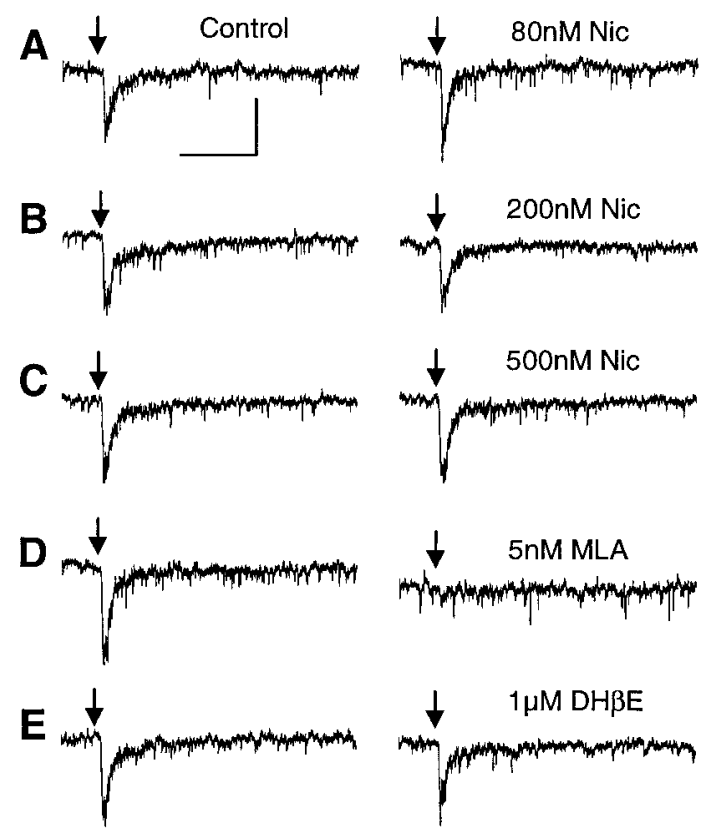

Figure 8. Exposure to low concentrations of nicotine does not desensitize the fast, MLA-

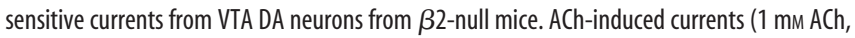
200 msec puff; arrows) are shown from the same neuron. Control currents are shown in the left panels, and currents obtained in the presence of nicotine are shown on the right at the concentrations given in $A-C . D$, The ACh-induced currents were inhibited by $5 \mathrm{~nm} M L A$. $E$, The AChinduced currents were not inhibited by $1 \mu \mathrm{m}$ DH $\beta$ E. Calibration: $25 \mathrm{pA}, 0.5 \mathrm{sec}$.

avoid desensitization (as described in Materials and Methods), the presence of fast, putative $\alpha 7^{\star}$ currents is underestimated in the VTA/SNc.

There are at least three caveats that limit the weight that should be placed on the finding that an $\alpha 7^{\star} \mathrm{nAChR}$ is present at low levels in the majority of VTA/SNc neurons, as estimated from choline-activated currents from $\alpha 7 \mathrm{~L} 250 \mathrm{~T}$ mice. One is that there is an $\alpha 4^{*}$ nAChR type in the VTA/SNc that also can be inhibited by MLA (Klink et al., 2001). However, because that nAChR type cannot be activated by choline (Klink et al., 2001), the results with choline-activated currents in $\alpha 7 \mathrm{~L} 250 \mathrm{~T}$ mice still support the common presence of the $\alpha 7$ subunit. The next potential problem is one of sampling. In other studies and this one, only a couple dozen neurons were examined to arrive at the estimates. By cutting slices slightly differently and choosing cells on the basis of visual cues, a different sampling process could occur between laboratories. A final point to consider is that these estimates for $\alpha 7$ in this study and others depend strongly on nAChR mutant mice. Although the general anatomical features are the same as in wild-type mice, there could be subtle changes arising from circuit differences during development, particularly when the $\alpha 7$ gene is altered (Broide et al., 1996; Adams et al., 2001). It can be concluded with certainty, nonetheless, that $\alpha 7^{\star}$ nAChRs are a low density but significant component in the VTA/SNc.

\section{$\alpha 7$ more common in VTA than $\mathrm{SNc}$ and $\alpha 7^{\star}$ nAChRs not} easily desensitized by smoker's nicotine

The second interesting result from this study is that the $\alpha 7^{*}$ type is more highly expressed in the rodent VTA than in the SNc. The $\left[{ }^{125} \mathrm{I}\right]-\alpha$-BTX binding, the in situ hybridization for $\alpha 7$ mRNA, and the current measurements all are consistent in indicating that the $\alpha 7$ subunit is present at a higher concentration in VTA neurons than in $\mathrm{SNc}$ neurons.

The third finding of interest is that the $\alpha 7^{\star} \mathrm{nAChR}$ type in the VTA/SNc is much less susceptible to desensitization by the low concentrations of nicotine achieved by smokers. This finding is the most likely to have important implications. Cigarette smoking delivers $\sim 50-300 \mathrm{~nm}$ nicotine throughout the brain on a time scale of many seconds to minutes (Russell, 1987; Benowitz et al., 1989; Henningfield et al., 1993; Gourlay and Benowitz, 1997). Significantly lower concentrations of nicotine will linger in the human brain for hours. We showed that a 20 min exposure to 80 nM nicotine caused $\sim 80 \%$ desensitization of the slower components of ACh-induced currents that are mediated predominantly by $\beta 2^{\star} \mathrm{nAChRs}$. This result is consistent with others who have estimated that $\alpha 4 \beta 2\left(^{*}\right)$ nAChRs have an $\mathrm{IC}_{50}$ for nicotineinduced desensitization of 1-60 nM (Lippiello et al., 1987; Wonnacott, 1987; Peng et al., 1994; Rowell, 1995; Fenster et al., 1999; Quick and Lester, 2002). However, up to 500 nm nicotine caused very little desensitization of the VTA/SNc $\alpha 7^{\star} \mathrm{nAChR}$ currents. This result may be surprising to some because high concentrations of agonist desensitize $\alpha 7^{\star}$ nAChRs more rapidly than other nAChR types (Alkondon and Albuquerque, 1991; Bertrand et al., 1992; Dani et al., 2000; Papke et al., 2000). Our results are consistent with others who have found that $\alpha 7^{\star}$ nAChRs from rodent hippocampus or expressed in oocytes are less easily desensitized by low nicotine concentrations. The $\mathrm{IC}_{50}$ estimates for nicotine-induced desensitization of $\alpha 7^{\star}$ nAChRs range from $\sim 0.5$ to $7 \mu \mathrm{M}$ (Fenster et al., 1997; Frazier et al., 1998; McQuiston and Madison, 1999; Alkondon et al., 2000; Quick and Lester, 2002).

\section{Significance of the differences in distribution and} desensitization of midbrain $\mathrm{nAChR}$ subtypes

Although neurons of the VTA and SNc have much in common, a number of studies have indicated anatomical, pharmacological, and electrophysiological differences (van Domburg and ten 
Donkelaar, 1991; Gardner and Ashby, 2000; Zhou et al., 2002). The roles of the VTA and SNc are not always separable, but there are some simplified distinctions. The SNc provides the main dopaminergic projections to the neostriatum and is mainly sensorimotor related. The VTA provides the main dopaminergic projections to the ventral striatum, the prefrontal cortex, and limbic areas, and the VTA participates in reinforcement and associative learning processes. Hence, it is mainly the VTA that projects to the areas in which dopaminergic mechanisms have been associated with drugs of addiction, including nicotine (Imperato et al., 1986; Clarke, 1991; Corrigall et al., 1992; Nisell et al., 1994, 1995; Pontieri et al., 1996; Di Chiara, 1999, 2000; Dani and De Biasi, 2001; Dani et al., 2001). Our results suggest another distinction: the VTA DA neurons have greater $\alpha 7^{\star}$ nAChR expression than the SNc DA neurons.

The literature supports the fact that nicotine addiction arises via processes involving $\alpha-\beta$ heteromeric nAChRs. $\beta 2^{\star}$ nAChRs support nicotine self-administration (Picciotto et al., 1998), and dopamine release driven by action potentials in the striatum strongly depends on $\beta 2^{\star}$ nAChRs (Zhou et al., 2001, 2002). Furthermore, $\alpha 4 \beta 2^{\star}$ receptors are high-affinity sites for nicotine (Picciotto et al., 1995; Zoli et al., 1998; Marubio et al., 1999). As shown here, however, after a short period of time, a smoker's level of nicotine will mainly desensitize $\alpha 4 \beta 2^{\star} \mathrm{nAChRs}$ (Lippiello et al., 1987; Wonnacott, 1987; Peng et al., 1994; Rowell, 1995; Pidoplichko et al., 1997; Fenster et al., 1999; Quick and Lester, 2002), but the $\alpha 7^{\star} \mathrm{nAChRs}$ remain functional at much higher nicotine concentrations (Fenster et al., 1997; Frazier et al., 1998; McQuiston and Madison, 1999; Alkondon et al., 2000; Quick and Lester, 2002). Therefore, after the $\beta 2^{\star}$ heteromeric nAChRs are essentially desensitized, $\alpha 7^{\star} \mathrm{nAChRs}$ are still mainly functional and better able to maintain their usual roles in the VTA/SNc. That difference in desensitization between $\alpha 4 \beta 2^{\star}$ nAChRs and $\alpha 7^{*}$ nAChRs on presynaptic afferents in the VTA is an important factor underlying nicotine-induced synaptic plasticity (Mansvelder and McGehee, 2000; Mansvelder et al., 2002). It was hypothesized that after a short exposure to nicotine, $\alpha 4 \beta 2^{\star} \mathrm{nAChRs}$ on GABAergic afferents are desensitized, decreasing GABA release and decreasing local inhibition of DA neurons. The $\alpha 7^{\star}$ $\mathrm{nAChRs}$ on glutamatergic afferents remain active and enhance glutamate excitation of the DA neurons (Dani et al., 2001). Together, these nicotine-altered mechanisms enhance long-term potentiation of excitatory inputs to the DA neurons and enhance the firing of DA neurons.

We should anticipate other complexities in the desensitization process when nicotine is present in the brain. Nicotine from tobacco will desensitize many nAChR types, but not in a uniform or invariant manner. Compositionally identical nAChRs can experience ongoing modifications that produce functional differences. Furthermore, extremely active nicotinic, cholinergic synapses will be more susceptible to desensitization by a smoker's nicotine. Nicotinic receptors at active synapses repeatedly experience brief exposures to $\sim 1 \mathrm{~mm}$ ACh. Normally, that very brief ACh exposure at a synapse might not produce desensitization. If the synaptic stimulation is extremely high, however, even the fast rates of recovery from desensitization may not allow complete recovery. When those events are occurring in conjunction with long exposure to low levels of nicotine, then we can expect that nAChRs located at active synapses are especially susceptible to desensitization. Evidence indicates that longer exposures to agonist allow slower rates of desensitization to come into play, such that nicotinic receptors can enter longer-lasting states of desensitization (Lester and Dani, 1994; Reitstetter et al., 1999). Fur- thermore, the recovery from desensitization can be variable, slow, complex, and species dependent (Olale et al., 1997; Dani et al., 2000; Quick and Lester, 2002).

What are the consequences of having many heteromeric nAChRs desensitized for relatively long periods? What roles did these receptors normally play that are now altered by nicotineinduced desensitization? Although nicotine self-administration and dopamine release depend on $\beta 2^{*}$ heteromeric nAChRs, the maintenance of $\alpha 7^{\star} \mathrm{nAChR}$ activity in the presence of low concentrations of nicotine also may be important and play presently unappreciated roles in nicotine addiction and synaptic plasticity linked to associative learning. It is particularly intriguing that DA and GABA neurons of the VTA, which is more involved in associative learning and the addiction process, express higher levels of $\alpha 7$ than the SNc in both rats and mice.

\section{References}

Adams CE, Stitzel JA, Collins AC, Freedman R (2001) Alpha 7-nicotinic receptor expression and the anatomical organization of hippocampal interneurons. Brain Res 922:180-190.

Alkondon M, Albuquerque EX (1991) Initial characterization of the nicotinic acetylcholine receptors in rat hippocampal neurons. J Recept Res 11:1001-1021.

Alkondon M, Pereira EF, Wonnacott S, Albuquerque EX (1992) Blockade of nicotinic currents in hippocampal neurons defines methyllycaconitine as a potent and specific receptor antagonist. Mol Pharmacol 41:802-808.

Alkondon M, Pereira EF, Cortes WS, Maelicke A, Albuquerque EX (1997) Choline is a selective agonist of alpha7 nicotinic acetylcholine receptors in the rat brain neurons. Eur J Neurosci 9:2734-2742.

Alkondon M, Pereira EF, Almeida LE, Randall WR, Albuquerque EX (2000) Nicotine at concentrations found in cigarette smokers activates and desensitizes nicotinic acetylcholine receptors in CA1 interneurons of rat hippocampus. Neuropharmacology 39:2726-2739.

Arroyo-Jimenez MM, Bourgeois JP, Marubio LM, Le Sourd AM, Ottersen OP, Rinvik E, Fairen A, Changeux J-P (1999) Ultrastructural localization of the $\alpha 4$-subunit of the neuronal acetylcholine nicotinic receptor in the rat substantia nigra. J Neurosci 19:6475-6487.

Azam L, Winzer-Serhan UH, Chen Y, Leslie FM (2002) Expression of neuronal nicotinic acetylcholine receptor subunit mRNAs within midbrain dopamine neurons. J Comp Neurol 444:260-274.

Balfour DJ, Wright AE, Benwell ME, Birrell CE (2000) The putative role of extra-synaptic mesolimbic dopamine in the neurobiology of nicotine dependence. Behav Brain Res 113:73-83.

Benowitz NL, Porchet H, Jacob P (1989) Nicotine dependence and tolerance in man: pharmacokinetic and pharmacological investigations. Prog Brain Res 79:279-287.

Berke JD, Hyman SE (2000) Addiction, dopamine, and the molecular mechanisms of memory. Neuron 25:515-532.

Bertrand D, Devillers-Thiery A, Revah F, Galzi JL, Hussy N, Mulle C, Bertrand S, Ballivet M, Changeaux JP (1992) Unconventional pharmacology of a neuronal nicotinic receptor mutated in the channel domain. Proc Natl Acad Sci USA 89:1261-1265.

Bonci A, Malenka RC (1999) Properties and plasticity of excitatory synapses on dopaminergic and GABAergic cells in the ventral tegmental area. J Neurosci 19:3723-3730.

Broide RS, Robertson RT, Leslie FM (1996) Regulation of $\alpha 7$ nicotinic acetylcholine receptors in the developing rat somatosensory cortex by thalamocortical afferents. J Neurosci 16:2956-2971.

Broide R, Salas R, Ji D, Paylor R, Patrick J, Dani J, De Biasi M (2002) Increased sensitivity to nicotine-induced seizures in mice expressing the L250T $\alpha 7$ nicotinic acetylcholine receptor mutation. Mol Pharmacol 61:1-10.

Calabresi P, Lacey MG, North RA (1989) Nicotinic excitation of rat ventral tegmental neurones in vitro studies by intracellular recording. Br J Pharmacol 98:135-140.

Castro NG, Albuquerque EX (1995) $\alpha$-Bungarotoxin-sensitive hippocampal nicotinic receptor channel has a high calcium permeability. Biophys J 68:516-524.

Champtiaux N, Han ZY, Bessis A, Rossi FM, Zoli M, Marubio L, McIntosh JM, Changeux JP (2002) Distribution and pharmacology of alpha 
6-containing nicotinic acetylcholine receptors analyzed with mutant mice. J Neurosci 22:1208-1217.

Charpantier E, Barnéoud P, Moser P, Besnard F, Sgard F (1998) Nicotinic acetylcholine subunit mRNA expression in dopaminergic neurons of the rat substantia nigra and ventral tegmental area. NeuroReport 9:3097-3101.

Clarke PB (1990) Mesolimbic dopamine activation-the key to nicotine reinforcement? Ciba Found Symp 152:153-168.

Clarke PB, Hommer DW, Pert A, Skirboll LR (1985) Electrophysiological actions of nicotine on substantia nigra single units. $\mathrm{Br} \mathrm{J}$ Pharmacol 85:827-835.

Clarke PBS (1991) The mesolimbic dopamine system as a target for nicotine. In: Effects of nicotine on biological systems (Adlkofer F, Thurau K, eds), pp 285-294. Basel: Birkhäuser Verlag.

Corrigall WA (1999) Nicotine self-administration in animals as a dependence model. Nicotine Tob Res 1:11-20.

Corrigall WA, Coen KM (1989) Nicotine maintains robust self-administration in rats on a limited-access schedule. Psychopharmacology (Berl) 99:473-478.

Corrigall WA, Franklin KB, Coen KM, Clarke PB (1992) The mesolimbic dopaminergic system is implicated in the reinforcing effects of nicotine. Psychopharmacology (Berl) 107:285-289.

Corrigall WA, Coen KM, Adamson KL (1994) Self-administered nicotine activates the mesolimbic dopamine system through the ventral tegmental area. Brain Res 653:278-284.

Dani JA, De Biasi M (2001) Cellular mechanisms of nicotine addiction. Pharmacol Biochem Behav 70:439-446.

Dani JA, Radcliffe KA, Pidoplichko V (2000) Variations in desensitization of nicotinic acetylcholine receptors from hippocampus and midbrain dopamine area. Eur J Pharmacol 393:31-38.

Dani JA, Ji D, Zhou FM (2001) Synaptic plasticity and nicotine addiction. Neuron 31:349-352.

Di Chiara G (1999) Drug addiction as dopamine-dependent associative learning disorder. Eur J Pharmacol 375:13-30.

Di Chiara G (2000) Role of dopamine in the behavioural actions of nicotine related to addiction. Eur J Pharmacol 393:295-314.

Di Chiara G, North RA (1992) Neurobiology of opiate abuse. Trends Pharmacol Sci 13:185-194.

Fenster CP, Rains MF, Noerager B, Quick MW, Lester RA (1997) Influence of subunit composition on desensitization of neuronal acetylcholine receptors at low concentrations of nicotine. J Neurosci 17:5747-5759.

Fenster CP, Whitworth TL, Sheffield EB, Quick MW, Lester RA (1999) Upregulation of surface $\alpha 4 \beta 2$ nicotinic receptors is initiated by receptor desensitization after chronic exposure to nicotine. J Neurosci 19:4804-4814.

Frazier CJ, Buhler AV, Weiner JL, Dunwiddie TV (1998) Synaptic potentials mediated via $\alpha$-bungarotoxin-sensitive nicotinic acetylcholine receptors in rat hippocampal interneurons. J Neurosci 18:8228-8235.

Gardner EL, Ashby CR Jr (2000) Heterogeneity of the mesotelencephalic dopamine fibers: physiology and pharmacology. Neurosci Biobehav Rev 24:115-118.

Goldner FM, Dineley KT, Patrick JW (1997) Immunohistochemical localization of the nicotinic acetylcholine receptor subunit $\alpha 6$ to dopaminergic neurons in the substantia nigra and ventral tegmental area. NeuroReport 8:2739-2742.

Gourlay SG, Benowitz NL (1997) Arteriovenous differences in plasma concentration of nicotine and catecholamines and related cardiovascular effects after smoking, nicotine nasal spray, and intravenous nicotine. Clin Pharmacol Ther 62:453-463.

Grace AA, Onn SP (1989) Morphology and electrophysiological properties of immunocytochemically identified rat dopamine neurons recorded in vitro. J Neurosci 9:3463-3481.

Gray R, Rajan AS, Radcliffe KA, Yakehiro, Dani JA (1996) Hippocampal synaptic transmission enhanced by low concentrations of nicotine. Nature 383:713-716

Grenhoff J, Aston-Jones G, Svensson TH (1986) Nicotinic effects on the firing pattern of midbrain dopamine neurons. Acta Physiol Scand 128:351-358.

Hausser M, Stuart G, Racca C, Sakmann B (1995) Axonal initiation and active dendritic propagation of action potentials in substantia nigra neurons. Neuron 15:637-647.

Henningfield JE, Stapleton JM, Benowitz NL, Grayson RF, London ED (1993) Higher levels of nicotine in arterial than venous blood after cigarette smoking. Drug Alcohol Depend 33:23-29.
Hyman SE, Malenka RC (2001) Addiction and the brain: the neurobiology of compulsion and its persistence. Nat Rev Neurosci 2:695-703.

Imperato A, Mulas A, Di Chiara G (1986) Nicotine preferentially stimulates dopamine release in the limbic system of freely moving rats. Eur J Pharmacol 132:337-338.

Ji D, Lape R, Dani JA (2001) Timing and location of nicotinic activity enhances or depresses hippocampal synaptic plasticity. Neuron 31:131-141.

Jones IW, Bolam JP, Wonnacott S (2001) Presynaptic localization of the nicotinic acetylcholine receptor beta2 subunit immunoreactivity in rat nigrostriatal dopaminergic neurones. J Comp Neurol 439:235-247.

Jones S, Sudweeks S, Yakel JL (1999) Nicotinic receptors in the brain: correlating physiology with function. Trends Neurosci 22:555-561.

Klink R, de Kerchove d'Exaerde A, Zoli M, Changeux JP (2001) Molecular and physiological diversity of nicotinic acetylcholine receptors in the midbrain dopaminergic nuclei. J Neurosci 21:1452-1463.

Lacey MG, Mercuri NB, North RA (1989) Two cell types in rat substantia nigra zona compacta distinguished by membrane properties and the actions of dopamine and opioids. J Neurosci 9:1233-1241.

Le Novère N, Zoli M, Changeux J-P (1996) Neuronal nicotinic receptor $\alpha 6$ subunit mRNA is selectively concentrated in catecholaminergic nuclei of rat brain. Eur J Neurosci 8:2428-2439.

Lester RAJ, Dani JA (1994) Time-dependant changes in central nicotinic acetylcholine channel kinetics in outside-out patches. Neuropharmacology 33:27-34.

Lippiello PM, Sears SB, Fernandes KG (1987) Kinetics and mechanism of $\mathrm{L}-\left[{ }^{3} \mathrm{H}\right]$ nicotine binding to putative high affinity receptor sites in rat brain. Mol Pharmacol 31:392-400.

Mansvelder HD, McGehee DS (2000) Long-term potentiation of excitatory inputs to brain reward areas by nicotine. Neuron 2000 27:349-357.

Mansvelder HD, Keath JR, McGehee DS (2002) Synaptic mechanisms underlie nicotine-induced excitability of brain reward areas. Neuron 33:905-919.

Marubio LM, del Mar Arroyo-Jimenez M, Cordero-Erausquin M, Lena C, Le Novere N, de Kerchove d'Exaerde A, Huchet M, Damaj MI, Changeux JP (1999) Reduced antinociception in mice lacking neuronal nicotinic receptor subunits. Nature 398:805-810.

McGehee DS, Role LW (1995) Physiological diversity of nicotinic acetylcholine receptors expressed by vertebrate neurons. Annu Rev Physiol 57:521-546.

McQuiston AR, Madison DV (1999) Nicotinic receptor activation excites distinct subtypes of interneurons in the rat hippocampus. J Neurosci 19:2887-2896.

Mercuri NB, Bonci A, Calabresi P, Stefani A, Bernardi G (1995) Properties of the hyperpolarization-activated cation current $I_{\mathrm{h}}$ in rat midbrain dopaminergic neurons. Eur J Neurosci 7:462-469.

Nestler EJ (1992) Molecular mechanisms of drug addiction. J Neurosci 12:2439-2450.

Nestler EJ (1993) Cellular responses to chronic treatment with drugs of abuse. Crit Rev Neurobiol 7:23-39.

Nestler EJ (1994) Molecular neurobiology of drug addiction. Neuropsychopharmacology 11:77-87.

Nisell M, Nomikos GG, Svensson TH (1994) Systemic nicotine-induced dopamine release in the rat nucleus accumbens is regulated by nicotinic receptors in the ventral tegmental area. Synapse 16:36-44.

Nisell M, Nomikos GG, Svensson TH (1995) Nicotine dependence, midbrain dopamine systems and psychiatric disorders. Pharmacol Toxicol 76:157-162.

Olale F, Gerzanich V, Kuryatov A, Wang F, Lindstrom J (1997) Chronic nicotine exposure differentially affects the function of human $\alpha 3, \alpha 4$ and $\alpha 7$ neuronal nicotinic receptor subtypes. J Pharmacol Exp Ther 283:675-683

Orr-Urtreger A, Goldner FM, Saeki M, Lorenzo I, Goldberg L, DeBiasi M, Dani JA, Patrick JW, Beaudet AL (1997) Mice deficient in the neuronal nicotinic $\alpha 7$ subunit lack $\alpha$-bungarotoxin binding sites and hippocampal fast nicotinic currents. J Neurosci 17:9165-9171.

Orr-Urtreger A, Broide RS, Kasten MR, Dang H, Dani JA, Beaudet AL, Patrick JW (2000) Mice homozygous for the L250T mutation in the $\alpha 7$ nicotinic acetylcholine receptor show increased neuronal apoptosis and die within 1 day of birth. J Neurochem 74:2154-2166.

Papke RL, Bencherif M, Lippiello P (1996) An evaluation of neuronal nicotinic acetylcholine receptor activation by quaternary nitrogen com- 
pounds indicates that choline is selective for the alpha 7 subtype. Neurosci Lett 213:201-204.

Papke RL, Meyer E, Nutter T, Uteshev VV (2000) $\alpha 7$ receptor-selective agonist and modes of $\alpha 7$ receptor activation. Eur J Pharmacol 393:179-195.

Paxinos G, Franklin KB (2000) The mouse brain in stereotaxic coordinates, Ed 2. New York: Academic.

Paxinos G, Watson C (1996) The rat brain in stereotaxic coordinates. New York: Academic.

Peng X, Gerzanich V, Anand R, Whiting PJ, Lindstrom J (1994) Nicotinicinduced increase in neuronal nicotinic receptors results from a decrease in the rate of receptor turnover. Mol Pharmacol 46:523-530.

Picciotto MR, Zoli M, Lena C, Bessis A, Lallemand Y, LeNovere N, Vincent P, Pich EM, Brulet P, Changeux JP (1995) Abnormal avoidance learning in mice lacking functional high-affinity nicotine receptor in the brain. $\mathrm{Na}-$ ture 374:65-67.

Picciotto MR, Zoli M, Rimondini R, Lena C, Marubio LM, Pich EM, Fuxe K, Changeux J-P (1998) Acetylcholine receptors containing the $\beta 2$ subunit are involved in the reinforcing properties of nicotine. Nature 391:173-177.

Pich EM, Pagliusi SR, Tessari M, Talabot-Ayer D, Hooft van Huijsduijnen R, Chiamulera C (1997) Common neural substrates for the addictive properties of nicotine and cocaine. Science 275:83-86.

Pidoplichko VI, DeBiasi M, Williams JT, Dani JA (1997) Nicotine activates and desensitizes midbrain dopamine neurons. Nature 390:401-404.

Pontieri FE, Tanda G, Orzi F, Di Chiara G (1996) Effects of nicotine on the nucleus accumbens and similarity to those of addictive drugs. Nature 382:255-257.

Quick MW, Lester RAJ (2002) Desensitization of neuronal nicotinic receptors. J Neurobiol 53:457-478.

Reitstetter R, Lukas RJ, Gruener R (1999) Dependence of nicotine acetylcholine receptor recovery from desensitization on the duration of agonist exposure. J Pharmacol Exp Ther 289:656-660.

Revah F, Bertrand D, Galzi JL, Devillers-Thiery A, Mulle C, Hussy N, Bertrand S, Ballivet M, Changeux JP (1991) Mutations in the channel domain alter desensitization of a neuronal nicotinic receptor. Nature $356: 846-849$

Role LW, Berg DK (1996) Nicotinic receptors in the development and modulation of CNS synapses. Neuron 16:1077-1085.

Rowell PP (1995) Nanomolar concentrations of nicotine increase the release of $\left[{ }^{3} \mathrm{H}\right]$ dopamine from rat striatal synaptosomes. Neurosci Lett 189:171-175.

Russell MA (1987) Estimation of smoke dosage and mortality of nonsmokers from environmental tobacco smoke. Toxicol Lett 35:9-18.
Séguéla P, Wadiche J, Dineley-Miller K, Dani JA, Patrick JW (1993) Molecular cloning, functional properties, and distribution of rat brain $\alpha 7$ : a nicotinic cation channel highly permeable to calcium. J Neurosci 13:596-604.

Stolerman IP, Shoaib M (1991) The neurobiology of tobacco addiction. Trends Pharmacol Sci 12:467-473.

van Domburg PH, ten Donkelaar HJ (1991) The human substantia nigra and ventral tegmental area. A neuroanatomical study with notes on aging and aging diseases. Adv Anat Embryol Cell Biol 121:1-132.

Wada E, Wada K, Boulter J, Deneris E, Heinemann S, Patrick J, Swanson LW (1989) Distribution of $\alpha 2, \alpha 3, \alpha 4$, and $\beta 2$ neuronal nicotinic receptor subunit mRNAs in the central nervous system: a hybridization histochemical study in the rat. J Comp Neurol 284:314-335.

Wada E, McKinnon D, Heinemann S, Patrick J, Swanson LW (1990) The distribution of mRNA encoded by a new member of the neuronal nicotinic acetylcholine receptor gene family $(\alpha 5)$ in the rat central nervous system. Brain Res 526:45-53.

Whiteaker P, Marks MJ, Grady SR, Lu Y, Picciotto MR, Changeux JP, Collins AC (2000) Pharmacological and null mutation approaches reveal nicotinic receptor diversity. Eur J Pharmacol 393:123-135.

Wonnacott S (1987) Brain nicotine binding sites. Hum Toxicol 6:343-353.

Wonnacott S (1997) Presynaptic nicotinic ACh receptors. Trends Neurosci 20:92-98.

Wonnacott S, Kaiser S, Mogg A, Soliakov L, Jones IW (2000) Presynaptic nicotinic receptors modulating dopamine release in the rat striatum. Eur J Pharmacol 393:51-58.

Xu W, Orr-Urtreger A, Nigro F, Gelber S, Sutcliffe CB, Armstrong D, Patrick JW, Role LW, Beaudet AL, De Biasi M (1999) Multi-organ autonomic dysfunction in mice lacking the $\beta 2$ and the $\beta 4$ subunits of neuronal nicotinic acetylcholine receptors. J Neurosci 19:9298-9305.

Yu CR, Role LW (1998) Functional contribution of the alpha7 subunit to multiple subtypes of nicotinic receptors in embryonic chick sympathetic neurones. J Physiol (Lond) 509:651-665.

Zhou FM, Liang Y, Dani JA (2001) Endogenous nicotinic cholinergic activity regulates dopamine release in the striatum. Nat Neurosci 4:1224-1229.

Zhou FM, Wilson CJ, Dani JA (2002) Cholinergic interneuron characteristics and nicotinic properties in the striatum. J Neurobiol 53:590-605.

Zoli M, Lena C, Picciotto MR, Changeux JP (1998) Identification of four classes of brain nicotinic receptors using $\beta 2$ mutant mice. J Neurosci 18:4461-4472.

Zwart R, Vijverberg HP (2000) Potentiation and inhibition of neuronal alpha4beta 4 nicotinic acetylcholine receptors by choline. Eur J Pharmacol 393:209-214. 